\title{
Influence of molding parameters on the properties of molding fuel derived form agroforestry biomass waste by pyrolysis
}

\author{
Yuxin Sun ${ }^{1}$, Jiaying $\mathrm{Xu}^{1}$, Meixuan $\mathrm{He}^{1}$, Yixuan Tang ${ }^{1}$, and Leichang $\mathrm{Cao}^{1 *}$ \\ ${ }^{1}$ Miami College, Henan University, Kaifeng 475004, China
}

\begin{abstract}
Biochar is now recognized as an excellent fuel with excellent performance in the combustion process and environmental friendness. As the main raw material of biochar, agricultural, and forestry biomass waste has a high waste rate. Therefore, researchers have conducted long-term research on the technology of generating biochar from agricultural and forestry biomass. Based on the current research and analysis of the existing molding fuel technology, the influence of different research parameters on the preparation of different biomass fuel is explored. The influences of molding temperature, molding pressure, raw material moisture content and the ratio of adhesive to toner on the performance of biomass fuel are focused on analysis. Finally, a conclusion is drawn based on the experimental data.
\end{abstract}

\section{Introduction}

Biomass is converted into biofuels through several ways, including biochemical, mechanical, and thermochemical processes. Thermochemical conversion methods include combustion, gasification, liquefaction, and pyrolysis [1]. At present, biomass can be developed and used in various ways. For example, palm oil residue biomass is used as a direct solid fuel instead of traditional diesel in Ecuador [2]. In addition, compared with traditional coal fuel, biomass charcoal molding fuel has the following advantages: high fuel purity; high calorific value; clean and hygienic; and no sulfur phosphorus.

At present, the main method for preparing biomass molding carbon fuel is to crush the biomass raw materials and then carbonize them. However, this method leads to a serious loss on equipment. For example, in Lithuania, about 3 million tons of stalks are collected yearly, but only $130,000-140,000$ tons are used for producing solid biofuel [3]. A new process was put forward as follows. The biomass is charred first and then ground to powder [4]. An increasing amount of attention is given to the preparation technology of this new biomass that can be used to form carbon fuel.

However, the waste rate of agroforestry biomass as raw material is very high. Learning about agriculture and forestry biomass pyrolysis carbonization molding fuel preparation research progress, knowing the basic mechanism and research status, understanding the transformation pathways of agriculture and forestry biomass pyrolysis carbonization, and analyzing the challenges of current research to promote the economic development globally (especially in rural areas) is very important for the preparation of molding pyrolytic carbon.

\section{Pyrolytic carbonization from agroforestry biomass}

Agroforestry biomass includes plants and plant-based materials and is specifically called lignocellulosic biomass Agroforestry biomass is a typical lignocellulosic biomass that is composed of a variety of complex organic polymers, such as cellulose, hemicellulose, and lignin [5-9].

Pyrolysis is the thermochemical decomposition of carbonaceous materials in an inert atmosphere at high temperature. In the biomass pyrolysis process, biochar, bio-oil, and volatile gas are usually generated [10]. Biomass is generally composed of cellulose, hemicellulose, and lignin. The decomposition temperature of cellulose is in the range of $325{ }^{\circ} \mathrm{C}-375{ }^{\circ} \mathrm{C}$, whereas those of hemicellulose and lignin are in the ranges of $225{ }^{\circ} \mathrm{C}-350{ }^{\circ} \mathrm{C}$ and $250{ }^{\circ} \mathrm{C}-500{ }^{\circ} \mathrm{C}$, respectively. Lignin decomposition begins at low temperatures (approximately $150{ }^{\circ} \mathrm{C}$ ) albeit at a very slow rate, because lignin has different chemical bonds and chemical bond energies, especially carbon-carbon bonds that require a high cracking temperature. At around $180{ }^{\circ} \mathrm{C}$, hemicellulose decomposition begins, followed by cellulose decomposition at approximately $260{ }^{\circ} \mathrm{C}$. These two polysaccharides decompose in a narrower temperature range (up to $400{ }^{\circ} \mathrm{C}$ ) and at a faster rate than lignin [1113].

In the preparation process of different specific fuels, the influence of different parameters on the fuel is high. Summarizing their rules is the main approach to elucidate the research progress on the preparation of pyrolytic carbonization molding fuel from agroforestry biomass in recent years (Tables 1, 2, and 3). 
Table 1. Influence of Temperature and Heating Rate on the Preparation of Different Fuels.

\begin{tabular}{|c|c|c|}
\hline Biomass & $\begin{array}{c}\text { Temperature } \\
\left({ }^{\circ} \mathrm{C}\right)\end{array}$ & $\begin{array}{l}\text { Heating rate } \\
\left({ }^{\circ} \mathrm{C} / \mathrm{min}\right)\end{array}$ \\
\hline Pine & 450 & l \\
\hline $\begin{array}{l}\text { Oak wood } \\
\text { and bark }\end{array}$ & I & l \\
\hline Herb residue & 400 & 100 \\
\hline Herb residue & 800 & 100 \\
\hline $\begin{array}{l}\text { Coconut } \\
\text { fiber }\end{array}$ & 300 & 15 \\
\hline $\begin{array}{l}\text { Refuse } \\
\text { derived fuel }\end{array}$ & 800 & 10 \\
\hline $\begin{array}{c}\text { Tamarind } \\
\text { seed }\end{array}$ & $120-455$ & 10 \\
\hline $\begin{array}{c}\text { Tamarind } \\
\text { seed }\end{array}$ & $100-500$ & 60 \\
\hline Jute stick & $220 \sim 390$ & 10 \\
\hline Jute stick & $200-460$ & 60 \\
\hline $\begin{array}{l}\text { Japanese } \\
\text { cedar }\end{array}$ & $200-330$ & 10 \\
\hline $\begin{array}{c}\text { Japanese } \\
\text { cedar }\end{array}$ & $210-390$ & 60 \\
\hline $\mathrm{RDF}$ & $300-500$ & I \\
\hline Cellulose & 300 & I \\
\hline HN coal & 650 & I \\
\hline Miscanthus & 300 & I \\
\hline PVC & $215 / 300$ & I \\
\hline Pine & 600 & 10 \\
\hline BAF & 250 & 10 \\
\hline BAF & 800 & 10 \\
\hline BAW & 250 & 10 \\
\hline BAW & 800 & 10 \\
\hline CTSWs & 350 & 20 \\
\hline CTSWs & 550 & 20 \\
\hline
\end{tabular}

\begin{tabular}{|c|c|c|}
\hline MSW & 700 & 30 \\
\hline MSW & 800 & 30 \\
\hline $\begin{array}{c}\text { Malewood } \\
\text { and } \\
\text { Malewood } \\
\text { leaves }\end{array}$ & 1300 & $/$ \\
\hline Rice husk & 1300 & $/$ \\
\hline
\end{tabular}

Table 2. Effect of Reaction time and Gas on the Preparation of Different Fuels.

\begin{tabular}{|c|c|c|}
\hline Biomass & $\begin{array}{c}\text { Reaction } \\
\text { time (h) }\end{array}$ & Gas \\
\hline Pine & 1 & $\mathrm{~N}_{2}$ \\
\hline $\begin{array}{l}\text { Oak wood } \\
\text { and bark }\end{array}$ & 0.5 & $\mathrm{~N}_{2}$ \\
\hline Herb residue & 0.43 & $\mathrm{~N}_{2}$ \\
\hline Herb residue & 0.43 & $\mathrm{~N}_{2}$ \\
\hline $\begin{array}{l}\text { Coconut } \\
\text { fiber }\end{array}$ & 0.34 & $\mathrm{Ar}$ \\
\hline $\begin{array}{c}\text { Refuse } \\
\text { derived fuel }\end{array}$ & 0.5 & $\begin{array}{c}\text { Inert } \\
\text { gas }\end{array}$ \\
\hline $\begin{array}{c}\text { Tamarind } \\
\text { seed }\end{array}$ & 0.3 & $\mathrm{~N}_{2}$ \\
\hline $\begin{array}{c}\text { Tamarind } \\
\text { seed }\end{array}$ & 0.1 & $\mathrm{~N}_{2}$ \\
\hline Jute stick & 0.23 & $\mathrm{~N}_{2}$ \\
\hline Jute stick & 0.1 & $\mathrm{~N}_{2}$ \\
\hline $\begin{array}{c}\text { Japanese } \\
\text { cedar }\end{array}$ & 0.21 & $\mathrm{~N}_{2}$ \\
\hline $\begin{array}{c}\text { Japanese } \\
\text { cedar }\end{array}$ & 0.26 & $\mathrm{~N}_{2}$ \\
\hline $\mathrm{RDF}$ & $0.34-1$ & $\mathrm{~N}_{2}$ \\
\hline Cellulose & / & $\begin{array}{c}\text { inert } \\
\text { gas }\end{array}$ \\
\hline HN coal & I & $\begin{array}{c}\text { Inert } \\
\text { gas }\end{array}$ \\
\hline Miscanthus & / & $\begin{array}{c}\text { Inert } \\
\text { gas }\end{array}$ \\
\hline PVC & I & $\begin{array}{c}\text { Inert } \\
\text { gas }\end{array}$ \\
\hline Pine & I & $\mathrm{Ar}$ \\
\hline
\end{tabular}




\begin{tabular}{|c|c|c|}
\hline BAF & $1 \mathrm{~h}$ & $\mathrm{~N}_{2}$ \\
\hline BAF & $1 \mathrm{~h}$ & $\mathrm{~N}_{2}$ \\
\hline BAW & $1 \mathrm{~h}$ & $\mathrm{~N}_{2}$ \\
\hline CTSWs & $0.34 \mathrm{~h}$ & $\mathrm{~N}_{2}$ \\
\hline CTSWs & $0.34 \mathrm{~h}$ & $\mathrm{~N}_{2}$ \\
\hline MSW & $0.5 \mathrm{~h}$ & $\mathrm{~N}_{2}$ \\
\hline $\begin{array}{c}\text { MSW } \\
\text { Malewood } \\
\text { and } \\
\text { Malewood } \\
\text { leaves }\end{array}$ & $0.5 \mathrm{~h}$ & $\mathrm{~N}_{2}$ \\
\hline $\begin{array}{c}\text { Rice husk } \\
\text { Bind }\end{array}$ & $12 \mathrm{~h}$ & $\mathrm{~N}_{2}$ \\
\hline
\end{tabular}

Table 3. Relevant Results of Table 1 and Table 2.

\begin{tabular}{|c|c|c|c|}
\hline Biomass & $\begin{array}{c}\text { Biochar } \\
\text { yield (\%) }\end{array}$ & $\begin{array}{l}\text { Calorific } \\
\text { value of } \\
\text { biochar }\end{array}$ & Reference \\
\hline Pine & $27.5 . \%$ & $26.5 \mathrm{MJ} / / \mathrm{kg}$ & [14] \\
\hline $\begin{array}{c}\text { Oak wood } \\
\text { and bark }\end{array}$ & $20 \%$ & $30 \mathrm{MJ} / / \mathrm{kg}$ & [14] \\
\hline Herb residue & $20 \%$ & $54 \mathrm{MJ} / / \mathrm{kg}$ & {$[15]$} \\
\hline Herb residue & $30 \%$ & I & [15] \\
\hline $\begin{array}{l}\text { Coconut } \\
\text { fiber }\end{array}$ & I & I & [16] \\
\hline $\begin{array}{c}\text { Refuse } \\
\text { derived fuel }\end{array}$ & I & I & [17] \\
\hline Biomass & $\begin{array}{c}\text { Biochar } \\
\text { yield (\%) }\end{array}$ & $\begin{array}{l}\text { Calorific } \\
\text { value of } \\
\text { biochar }\end{array}$ & [18] \\
\hline $\begin{array}{c}\text { Tamarind } \\
\text { seed }\end{array}$ & $24.5 \%$ & $16.0 \mathrm{~kJ} / \mathrm{mol}$ & [18] \\
\hline $\begin{array}{c}\text { Tamarind } \\
\text { seed }\end{array}$ & $22.8 \%$ & $16.3 \mathrm{~kJ} / \mathrm{mol}$ & [18] \\
\hline Jute stick & $15.6 \%$ & $42.9 \mathrm{~kJ} / \mathrm{mol}$ & [18] \\
\hline Jute stick & $14.5 \%$ & $44.2 \mathrm{~kJ} / \mathrm{mol}$ & [18] \\
\hline
\end{tabular}

\begin{tabular}{|c|c|c|c|}
\hline $\begin{array}{c}\text { Japanese } \\
\text { cedar }\end{array}$ & $13.5 \%$ & $22.1 \mathrm{~kJ} / \mathrm{mol}$ & {$[18]$} \\
\hline $\begin{array}{c}\text { Japanese } \\
\text { cedar }\end{array}$ & $12.6 \%$ & $25.2 \mathrm{~kJ} / \mathrm{mol}$ & {$[18]$} \\
\hline RDF & $/$ & $19-21 \mathrm{MJ} / \mathrm{k}$ & {$[19]$} \\
\hline Cellulose & $/$ & $/$ & {$[20]$} \\
\hline HN coal & $/$ & $/$ & {$[21]$} \\
\hline Miscanthus & $/$ & $/$ & {$[21]$} \\
\hline PVC & $/$ & $/$ & {$[21]$} \\
\hline Pine & $65 \%$ & $/$ & {$[22]$} \\
\hline BAF & $72 \%$ & $21.3 \mathrm{MJ} / / \mathrm{kg}$ & {$[22]$} \\
\hline BAF & $32 \%$ & $28.0 \mathrm{MJ} / / \mathrm{kg}$ & {$[22]$} \\
\hline BAW & $74 \%$ & $21.4 \mathrm{MJ} / / \mathrm{kg}$ & {$[22]$} \\
\hline BAW & $24 \%$ & $27.0 \mathrm{MJ} / / \mathrm{kg}$ & {$[23]$} \\
\hline CTSWs & $67.5 \%$ & $21.8 \mathrm{MJ} / / \mathrm{kg}$ & {$[23]$} \\
\hline CTSWs & $33.2 \%$ & $19.9 \mathrm{MJ} / / \mathrm{kg}$ & {$[24]$} \\
\hline MSW & $25.9 \%$ & $/$ & {$[24]$} \\
\hline MSW & $35.1 \%$ & $/$ & {$[25]$} \\
\hline
\end{tabular}

\section{Influence of molding process parameters on the properties of molding fuel}

\subsection{Molding temperature}

The carbonization temperature of biomass affects the physical properties of biochar [26] (Table 4). Mochizuki et al. [27] found that the specific surface area of the coke and tar obtained from wood chips pyrolysis reached the maximum value at $550{ }^{\circ} \mathrm{C}$, and the tensile strength of the obtained molded coke decreased with increasing molding temperature. In a study investigating the preparation of straw biochar, Wang et al. [28] found that reducing the heating rate and prolonging the carbonization time could improve the specific surface area, pore volume, and pore size of straw biochar.

When Oginni et al. [29] studied the carbonization temperature of white pine and Norway spruce needle biochar fuel, they found that with increasing carbonization temperature, the ignition temperature of white pine needle biochar increases.

When Xu et al. [30] studied the influence of pyrolysis temperature on the nitrogen content in biochar and compared it with hydrogenation carbon. They found that the nitrogen content in biochar is positively correlated with the biomass nitrogen content and negatively correlated with the pyrolysis temperature. Heating rate has 
a significant effect on the conversion rate of biomass charcoal [31-34].

Table 4. Specific Examples of the Effect of Molding Temperature on Biomass Carbon.

\begin{tabular}{|l|l|l|l|}
\hline Biomass & $\begin{array}{l}\text { forming } \\
\text { temperature }\end{array}$ & $\begin{array}{l}\text { Biochar } \\
\text { properties }\end{array}$ & Reference \\
\hline $\begin{array}{l}\text { Wood } \\
\text { chips }\end{array}$ & $\begin{array}{l}\text { The } \\
\text { temperature is } \\
\text { on the rise }\end{array}$ & $\begin{array}{l}\text { The intensity } \\
\text { becomes low }\end{array}$ & $\begin{array}{l}\text { Yuuki } \\
\text { Mochizuki }\end{array}$ \\
\hline straw & $\begin{array}{l}\text { Reduced specific } \\
\text { surface area, } \\
\text { pore volume } \\
\text { and pore size } \\
\text { of biochar } \\
\text { were rate } \\
\text { increased }\end{array}$ & Hanxi \\
Wang \\
\hline $\begin{array}{l}\text { White } \\
\text { pine and } \\
\text { Norway } \\
\text { spruce } \\
\text { needle }\end{array}$ & $\begin{array}{l}\text { The } \\
\text { carbonization } \\
\text { temperature } \\
\text { increases }\end{array}$ & $\begin{array}{l}\text { Ignition } \\
\text { temperature } \\
\text { rise }\end{array}$ & $\begin{array}{l}\text { Oluwatosin } \\
\text { Oginni }\end{array}$ \\
\hline
\end{tabular}

\subsection{Moisture content}

The moisture content of biochar powder has a significant effect on the tensile and compressive properties of the formed biochar. When Bazargan et al. [35] studied palm kernel shell biochar, they found that with decreasing water content, the tensile and compressive strengths of starchbound briquette increase. They speculated that the evaporation of water in the starch-bound sample could better cement the starch and the particles.

Water content has a significant influence on the mechanical properties of biomass fuels. Espuelas et al. [36] found that xanthan and guar gums could produce briquette with good mechanical properties when they studied the application of low energy consumption coffee ground and organic binder compaction to the production of biomass fuel. However, high moisture content is required for effectiveness. By conducting experiments, the authors found that the best briquette can be produced by using $5 \%$ xanthan gum and $30 \%$ moisture.

\subsection{Ratio of binder and charcoal powder}

Kumar et al. [37] found that the calorie-value of pure charcoal is higher than that of a binder consisting of starch, charcoal, and biomass, but the addition of binder reduces ash moisture content and volatile matter content, thereby reducing the corrosion effect. Mochizuki et al. [27] found that increasing the mix ratio of $\mathrm{CC} 250$ and binder coal reduces the strength of coke, but the degree of reduction in intensity is less than that of the mix ratio of mild binder coal, coke, and binder coal.

\section{Conclusion}

The specific preparation process still faces great challenges. First, the properties of fuel generated by pyrolytic carbonization of agroforestry biomass are highly dependent on raw material types and operating conditions in the thermochemical process, especially in the slow pyrolysis process $[38,39]$. In general, the influence of substance type and baking temperature on biomaterals is studied through many indexes, such as elemental composition, industrial analysis, bulk density, energy content, and hygroscopicity [40]. Another problem is related to feedstock impurities. Excess residual impurities in agroforestry biomass may clog the reactor [41,42]. Meeting these requirements with ensuring economic benefits is still a problem.

\section{References}

1. Bridgwater, A.V., Review of fast pyrolysis of biomass and product upgrading. Biomass Bioenerg. 2012, 38, 68-94.

2. Heredia Salgado, M.A.; Tarelho, L.a.C.; Matos, M.a.A.; Rivadeneira, D.; Narváez C, R.A., Palm oil kernel shell as solid fuel for the commercial and industrial sector in Ecuador: tax incentive impact and performance of a prototype burner. J. Clean. Prod. 2019, 213, 104-113.

3. Kulokas, M.; Praspaliauskas, M.; Pedišius, N., Investigation of buckwheat hulls as additives in the production of solid biomass fuel from straw. Energies 2021, 14, (2), 265.

4. Kizuka, R.; Ishii, K.; Ochiai, S.; Sato, M.; Yamada, A.; Nishimiya, K., Improvement of biomass fuel properties for rice straw pellets using torrefaction and mixing with wood chips. Waste Biomass Valori. 2020.

5. Barta, K.; Ford, P.C., Catalytic conversion of nonfood woody biomass solids to organic liquids. Acc. Chem. Res. 2014, 47, (5), 1503-12.

6. Alhassan, Y.; Kumar, N.; Bugaje, I.M., Hydrothermal liquefaction of de-oiled Jatropha curcas cake using Deep Eutectic Solvents (DESs) as catalysts and cosolvents. Bioresour. Technol. 2016, 199, 375-381.

7. Durak, H.; Aysu, T., Structural analysis of bio-oils from subcritical and supercritical hydrothermal liquefaction of Datura stramonium L. J. Supercrit. Fluid. 2016, 108, 123-135.

8. Raikova, S.; Smith-Baedorf, H.; Bransgrove, R.; Barlow, O.; Santomauro, F.; Wagner, J.L.; Allen, M.J.; Bryan, C.G.; Sapsford, D.; Chuck, C.J., Assessing hydrothermal liquefaction for the production of biooil and enhanced metal recovery from microalgae cultivated on acid mine drainage. Fuel Process. Technol. 2016, 142, 219-227.

9. Gerber Van Doren, L.; Posmanik, R.; Bicalho, F.A.; Tester, J.W.; Sills, D.L., Prospects for energy recovery during hydrothermal and biological processing of waste biomass. Bioresour. Technol. 2017, 225, 67-74.

10. Kostas, E.T.; Durán-Jiménez, G.; Shepherd, B.J.; Meredith, W.; Stevens, L.A.; Williams, O.S.A.; Lye, G.J.; Robinson, J.P., Microwave pyrolysis of olive pomace for bio-oil and bio-char production. Chem. Eng. J. 2020, 387, 123404.

11. Rodriguez Correa, C.; Otto, T.; Kruse, A., Influence of the biomass components on the pore formation of 
activated carbon. Biomass Bioenerg. 2017, 97, 53-64.

12. Allan G. W. Bradbury, Y.S., And Fred Shafizadeh,, A kinetic model for pyrolysis of cellulose. J. Appl. Polym. Sci. 1979, 23,3271-3280 (1979).

13. G, V.; P, S.O.; L, M.S., Kinetics of the thermal decomposition of cellulose in sealed vessels at elevated pressures. Effects of the presence of water on the reaction mechanism. J. Anal. Appl. Pyrolysis 1993.

14. Yang, Y.; Brammer, J.G.; Mahmood, A.S.N.; Hornung, A., Intermediate pyrolysis of biomass energy pellets for producing sustainable liquid, gaseous and solid fuels. Bioresour. Technol. 2014, 169, 794-799.

15. Dong, P.; Chen, G.; Zeng, X.; Chu, M.; Gao, S.; Xu, G., Evolution of inherent oxygen in solid fuels during pyrolysis. Energ. Fuel. 2015, 29, (4), 2268-2276.

16. Liu, Z.; Han, G., Production of solid fuel biochar from waste biomass by low temperature pyrolysis. Fuel 2015, 158, 159-165.

17. Manyà, J.J.; García-Ceballos, F.; Azuara, M.; Latorre, N.; Royo, C., Pyrolysis and char reactivity of a poorquality refuse-derived fuel (RDF) from municipal solid waste. Fuel Process. Technol. 2015, 140, 276284.

18. Tuly, S.S.; Rahman, M.S., Pyrolysis kinetics study of three biomass solid wastes for thermochemical conversion into liquid fuels. AIP Conf. Proc. 2017, 1851

19. Sygula, E.; Swiechowski, K.; Stepien, P.; Koziel, J.A.; Bialowiec, A., The prediction of calorific value of carbonized solidfuel produced from refuse-derived fuel in the low-temperature pyrolysis in $\mathrm{CO} 2$. Materials 2020, 14, (1).

20. Wang, Y.; Zhu, Y.; Zhou, Z.; Yang, J.; Pan, Y.; Qi, F., Pyrolysis study on solid fuels: from conventional analytical methods to synchrotron vacuum ultraviolet photoionization mass spectrometry. Energ. Fuel. 2016, 30, (3), 1534-1543.

21. Younan, Y.; Van Goethem, M.W.M.; Stefanidis, G.D., A particle scale model for municipal solid waste and refuse-derived fuels pyrolysis. Comput. Chem. Eng. 2016, 86, 148-159.

22. Mokrzycki, J.; Gazińska, M.; Fedyna, M.; Karcz, R.; Lorenc-Grabowska, E.; Rutkowski, P., Pyrolysis and torrefaction of waste wood chips and cone-like flowers derived from black alder (Alnus glutinosa L. Gaertn.) for sustainable solid fuel production. Biomass Bioenerg. 2020, 143, 105842.

23. Zhang, H.; Zhang, X.; Shao, J.; Wang, H.; Zhang, S.; Chen, H., Effect of temperature on the product characteristics and fuel-nitrogen evolution during chromium-tanned solid wastes pyrolysis polygeneration. J. Clean. Prod. 2020, 254, 120020.

24. Veses, A.; Sanahuja-Parejo, O.; Callen, M.S.; Murillo, R.; Garcia, T., A combined two-stage process of pyrolysis and catalytic cracking of municipal solid waste for the production of syngas and solid refusederived fuels. Waste Manage. 2020, 101, 171-179.

25. Kan, T.; Strezov, V.; Evans, T.J., Lignocellulosic biomass pyrolysis: A review of product properties and effects of pyrolysis parameters. Renew. Sust. Enegy. Rev. 2016, 57, 1126-1140.

26. Wang, K.; Peng, N.; Lu, G.; Dang, Z., Effects of pyrolysis temperature and holding time on physicochemical properties of swine-manure-derived biochar. Waste Biomass Valori. 2018, 11, (2), 613-624

27. Mochizuki, Y.; Tsubouchi, N., Preparation of pelletized coke by co-carbonization of caking coal and pyrolyzed char modified with tar produced during pyrolysis of woody biomass. Fuel Process. Technol. 2019, 193, 328-337.

28. Wang, H.; Xu, J.; Sheng, L., Preparation of straw biochar and application of constructed wetland in China: A review. J. Clean. Prod. 2020, 273, 123131.

29. Oginni, O.; Singh, K., Effect of carbonization temperature on fuel and caffeine adsorption characteristics of white pine and Norway spruce needle derived biochars. Ind. Crop. Prod. 2021, 162, 113261.

30. Xu, S.; Chen, J.; Peng, H.; Leng, S.; Li, H.; Qu, W.; Hu, Y.; Li, H.; Jiang, S.; Zhou, W.; Leng, L., Effect of biomass type and pyrolysis temperature on nitrogen in biochar, and the comparison with hydrochar. Fuel 2021, 291, 120128.

31. Liu, J.; Huang, S.; Chen, K.; Wang, T.; Mei, M.; Li, J., Preparation of biochar from food waste digestate: Pyrolysis behavior and product properties. Bioresour. Technol. 2020, 302, 122841.

32. Ahmad, J.; Patuzzi, F.; Rashid, U.; Shahabz, M.; Ngamcharussrivichai, C.; Baratieri, M., Exploring untapped effect of process conditions on biochar characteristics and applications. Environ. Technol. Inno. 2021, 21, 101310.

33. Pan, X.; Gu, Z.; Chen, W.; Li, Q., Preparation of biochar and biochar composites and their application in a Fenton-like process for wastewater decontamination: A review. Sci. Total Environ. 2021, 754, 142104.

34. Zhang, X.; Gao, B.; Zhao, S.; Wu, P.; Han, L.; Liu, X., Optimization of a "coal-like" pelletization technique based on the sustainable biomass fuel of hydrothermal carbonization of wheat straw. J. Clean. Prod. 2020, 242, 118426.

35. Bazargan, A.; Rough, S.L.; Mckay, G., Compaction of palm kernel shell biochars for application as solid fuel. Biomass Bioenerg. 2014, 70, 489-497.

36. Espuelas, S.; Marcelino, S.; Echeverría, A.M.; Del Castillo, J.M.; Seco, A., Low energy spent coffee grounds briquetting with organic binders for biomass fuel manufacturing. Fuel 2020, 278, 118310.

37. Ajith Kumar, J.; Vinoth Kumar, K.; Petchimuthu, M.; Iyahraja, S.; Vignesh Kumar, D., Comparative analysis of briquettes obtained from biomass and charcoal. Biomass Bioenerg. 2020.

38. Stelte, W.; Holm, J.K.; Sanadi, A.R.; Barsberg, S.; Ahrenfeldt, J.; Henriksen, U.B., A study of bonding and failure mechanisms in fuel pellets from different 
biomass resources. Biomass Bioenerg. 2011, 35, (2), 910-918.

39. Ferraro, G.; Pecori, G.; Rosi, L.; Bettucci, L.; Fratini, E.; Casini, D.; Rizzo, A.M.; Chiaramonti, D., Biochar from lab-scale pyrolysis: influence of feedstock and operational temperature. Biomass Convers. Bior. 2021.

40. Kethobile, E.; Ketlogetswe, C.; Gandure, J., Torrefaction of non - oil Jatropha curcas L. (Jatropha) biomass for solid fuel. Biomass Bioenerg. 2020, 6, (12), e05657.

41. Bach, Q.-V.; Skreiberg, , Upgrading biomass fuels via wet torrefaction: A review and comparison with dry torrefaction. Renew. Sust. Enegy. Rev. 2016, 54, 665677.

42. Hassan, S.S.; Williams, G.A.; Jaiswal, A.K., Emerging technologies for the pretreatment of lignocellulosic biomass. Bioresour. Technol. 2018, 262, 310-318. 